\title{
EDITORIAL
}

\section{Schistosoma mansoni ASSOCIATED GLOMERULOPATHY}

\author{
T. DE BRITO(1), I. NUSSENZVEIG(2), Célia R.W. CARNEIRO(3) \& Ana Maria G. SILVA(1)
}

The incidence of nephrotic syndrome and chronic renal failure is much higher in tropical than in temperate climates, suggesting that parasitic diseases might be involved in the pathogenesis of glomerular disease in such areas.

A possible association between $S$. mansoni infection and renal lesions has been suspected by clinicians for some time. Earlier observations were based on features such as proteinuria and the presence of morphologic abnormalities in renal biopsies or autopsy material.

The overall incidence of glomerular disease and schistosomiasis was shown to be about 5-6\%, whereas in patients with the hepatosplenic form of the disease the incidence increased to $15 \%{ }^{41}$.

In $S$. mansoni infection, circulating antigens derive from the adult worm (gut antigens) or from the schistosome eggs and are demonstrable in various fluids of the host. The kidneys play an important role in the disposal of circulating antigens. Therefore, a close relationship was established between the continuous offer of schistosomal antigens to the kidney and glomerular lesions. In hepatosplenic schistosomiasis the shunting of portal blood carrying the primary load of antigens into the systemic circulation is the main mechanism by which the liver may be excluded from processing the schistosomal antigens which are then offered to the kidneys in larger amounts. In addition, it was shown that the severity of glomerular lesions, as well as proteinuria, might be correlated with impairment of hepatic macrophage function ${ }^{8}$. If the association of parasitic antigen/s and glomerular disease indicates a cause/ effect relationship, these findings might explain the presence of renal lesions not only in hepatosplenic schistosomiasis but also in patients with the hepato-intestinal form of the disease ${ }^{1}$.

Schistosomal antigens were demonstrated in the glomeruli of humans with active schistosomiasis mansoni for the first time in a transplanted kidney of a patient with focal and segmental glomerulosclerosis ${ }^{19}$ and afterwards in patients with mesangioproliferative glomerulonephritis ${ }^{22}$. The acidic elution of immunoglobulins from the kidneys permitted the demonstration of their specific binding to the gut region of the adult worm $^{22,29}$. Membranoproliferative glomerulonephritis has been frequently observed in patients with hepatosplenic schistosomiasis ${ }^{13}$. SOBH et al. ${ }^{36}$, using a monoclonal antibody, demonstrated schistosomal antigen deposits by immunofluorescence techniques in 12 of 17 patients with different patterns of advanced glomerular disease but with a predominance of type 1 membranoproliferative glomerulonephritis .

Schistosomal antigen/s were first demonstrated experimentally in glomeruli of mice by NATALI \& CIOLI ${ }^{31}$. Similarly to humans, antigen deposits were accompanied by lesions localized mainly in the mesangial area. Immunoglobulins (mainly IgM and IgG) and C3 were also detected. Afterwards, animal models for studies of renal lesions associated with schistosomal infections were established in a variety of animals, from mice and hamsters to chimpanzees ${ }^{23}$. Both worm and egg antigens were detected in some of the experimental animals ${ }^{14,23}$ in contrast to the generally accepted feeling that egg antigens were related only to lesions of the liver and other organs but not to the glomerular alterations. However, in the glomerular deposits there was a predominance of the gut over the egg antigen $/ \mathrm{s}^{14}$.

Under experimental conditions, mesangioproliferative glomerulonephritis is the usual manifestation of glomerular disease in schistosomiasis. Only $\mathrm{HOUBA}^{23}$ reported on the occurrence of membranoproliferative glomerulonephritis in Kenyan baboons (Papio anubis) infected with Schistosoma mansoni. Interestingly, the presence of antigens without any immunoglobulins in the glomeruli was reported in a few animals. This finding suggests that antigens may be deposited ("planted") directly in the glomeruli.

It is admitted that the initial glomerular injury in human schistosomiasis is a mesangioproliferative glomerulonephritis ${ }^{4,6}$ mediated chiefly by worm (gut) antigens, which have been detected as circulating antigen/s in infected patients as well as in experimental animals $\mathrm{s}^{7,16,17}$. Specific antibodies of all major immunoglobulin classes have also been detected in the sera of both humans and experimental animals. Therefore, a glomerular inflammatory injury which occurs as a consequence of glomerular immune-complex deposition was suggested as the more probable mechanism of the glomerulopathies detected in mansonian schistosomiasis ${ }^{2,7,10}$. The immune deposits may form in the glomerular capillary not only by deposition from the circulation but also locally after binding with previously "planted" schistosomal antigen/s. Molecular charge influences the binding of circulating antigens to the glomerular basement membrane which, due to its high content of heparan sulphate proteoglycans, is negatively charged ${ }^{2}$.

(1)Institute of Tropical Medicine, São Paulo, SP, Brasil.

(2)Division of Nephrology, "Hospital das Clinicas", University of S. Paulo, Medical School, S. Paulo, SP, Brasil.

(3)São Paulo Federal University Medical School, Dept. of Microbiology, Immunology, and Parasitology, S. Paulo, SP, Brazil

Correspondence to: Dr. Thales De Brito, Av. Dr. Enéas de Carvalho Aguiar 470, 05403-000 S. Paulo, SP, Brazil. E- Mail: thalesbr@usp.br 
Cure of schistosomiasis does not stop the progression of glomerular disease in humans or experimental animals ${ }^{8,38}$. These data may suggest that, despite the importance of the schistosomal antigen/s in the initiation of glomerular injury, other factors such as autoimmunity may play a role in the further evolution of the lesions ${ }^{8}$.

Several patterns of glomerular pathology have been described associated with mansonian schistosomiasis and a histopathological classification was suggested by BARSOUM ${ }^{8}$. Groups comprised different grades of mesangioproliferative glomerulonephritis, exudative glomerulonephritis (associated with Salmonella infection), membranoproliferative type I (more common) and type III glomerulonephritis, focal and segmental glomerulosclerosis, and amyloidosis. Progression between these groups has been demonstrated, particularly between the mesangioproliferative and membranoproliferative forms ${ }^{13}$. BARSOUM ${ }^{8}$ also reviewed the prevalence of the main patterns of glomerular injury associated with mansonian schistosomiasis. Mesangioproliferative glomerulonephritis has been described in 26.7 to $60 \%$ of asymptomatic patients and in 10 to $41.2 \%$ of those with manifest renal disease. Membranoproliferative glomerulonephritis was the more frequent pattern described in symptomatic patients $(80 \%)$. The prevalence of focal and segmental glomerulosclerosis associated with mansonian schistosomiasis varies in different series from 11.2 to $38 \%$. In all instances schistosomal antigen/s have been demonstrated in glomeruli by different techniques which included immunofluorescence and immunoelectron microscopy.

It is worth noting that false-positive reactions for schistosoma antigen/s can be seen by immunoelectron microscopy in patients with a positive serology for hepatitis C (DE BRITO, T., unpublished data). The possibility has been raised of a correlation of false-positive serologic tests for hepatitis $\mathrm{C}$, high IgG concentration and circulating immune-complexes, conditions which are common in patients with schistosomiasis ${ }^{3,21}$.

There is good reason to believe that the patterns of glomerular injury described in schistosomiasis may reflect the influence of certain geographical factors and perhaps pathogenetic differences ${ }^{8}$. Amyloidosis, for example, is seldom seen by us as a complication of advanced glomerulopathy associated with schistosomiasis. Also, a significant frequency of $\operatorname{IgA}$ deposits in renal biopsies from patients with overt glomerulopathy associated with schistosomiasis, as described by BARSOUM et al. ${ }^{9}$ and supported by experimental data ${ }^{18}$, is not frequently found among us ${ }^{15}$.

Membranous glomerulopathy is seldom described in association with mansonian schistosomiasis 5 . It is well known that this nephropathy can appear as a complication of various infectious diseases ${ }^{12,20,26,27,30,32,40}$. In some conditions, like syphilis ${ }^{24,32,40}$ and malaria ${ }^{20}$, patients manifest a nephrotic syndrome which is resolved with specific treatment, thus strongly suggesting that the infectious agent is the cause of the disease. In other instances, however, the possibility of coincidental pathologies cannot be entirely discarded ${ }^{30}$.

Focal and segmental glomerulosclerosis is a common and nonspecific pattern of glomerular injury that can occur in three groups of disease processes: as a primary or idiopathic disease with diffuse damage and effacement or simplification of the foot process, as segmental scarring secondary to an active glomerulitis and in a variety of clinical settings with prior loss of functioning nephron units and hemodynamic changes that result in significant capillary hypertension. The first two instances should be considered in association with schistosomiasis.

Schistosomal antigens were detected by us by immunoelectron microscopy ${ }^{15}$ in glomeruli of two patients with focal and segmental glomerulosclerosis. Both patients exhibited small deposits of $\mathrm{C} 3$ and one of them had also traces of $\operatorname{IgM}$ in the glomeruli as detected by immunofluorescence, findings which can be present in this glomerulopathy ${ }^{11}$. A third patient with active schistosomiasis mansoni and negative immunoglobulins deposits, features of minimal change disease, also had glomerular antigen deposits. In spite of areas of slight mesangial proliferation and occasional ultrastructural electron-dense deposits, which might be ascribed to the antigen deposits, the clinical and ultrastructural features were of minimal change disease ${ }^{11}$. This patient had an excellent corticosteroid therapy response within a one year follow-up. Classic immune complex mechanisms are excluded in the pathogenesis of minimal change disease but it is probable that some immune dysfunction is present associated with $\mathrm{T}$ cell immunity. Alternatively, immune complexes can interact with cells in the circulation or other tissues and initiate the release of inflammatory mediators which are delivered to the kidney where they induce proteinuria and circulatory changes ${ }^{2}$. This mechanism might play a role in minimal change disease and in idiopathic focal and segmental glomerulosclerosis in which immunoglobulin deposits are scarce or, more frequently, absent. It is worth mentioning that minimal change disease and focal and segmental glomerulosclerosis are regarded by some as two extremes of one spectrum and probably represent different stages in the evolution of a single disease ${ }^{34}$.

KEVIN KRANE et al. ${ }^{26}$ described for the first time minimal change disease associated with syphilis. The causative association of the two entities was supported by the response of the nephrotic syndrome to the treatment of the treponemal infection. Therefore, infectious diseases can determine kidney changes similar to those of minimal change disease by an unknown mechanism.

Consequently, many different patterns of glomerular injury may be present in human schistosomiasis. Although different glomerular responses can be mediated by a single infectious agent and/or its antigen/s such as hepatitis $\mathrm{B}$ and $\mathrm{C}$ virus ${ }^{12,25,27,39}$, it should be pointed out that the possibility of passive schistosomal antigen/s entrapment in a diseased glomerulus without a causal relationship cannot be completely ruled out. In this respect, a close resemblance between the questions raised regarding the pathogenesis of the renal lesions in schistosomiasis and hepatitis $C$ virus glomerulopathy is observed. In both conditions different glomerular patterns are reported ${ }^{12,25}$, and the $\mathrm{C}$ virus was detected in the glomeruli of patients affected by the more common glomerular manifestation ${ }^{42}$. Also, in hepatitis C-associated glomerulopathy it was considered that even if the virus ${ }^{42}$ and possibly specific antigen/s are present in the glomeruli, they cannot be assumed to have a pathogenetic role, since they may reflect their trapping at sites of tissue injury ${ }^{25}$.

However, as far as schistosomiasis is concerned, experimental and epidemiological evidence suggests mesangioproliferative and membranoproliferative glomerulonephritis to be the more frequent manifestation of renal disease associated with mansonian schistosomiasis $4,6,7,13,33,35,37$. Focal and segmental glomerulosclerosis secondary to glomerulitis might also be related to the deposition of schistosomal antigen/s. 
On the other hand, we might speculate that host factors and the amount and frequency of antigen supply may determine different glomerular responses. Furthermore, even the passive entrapment of schistosomotic antigen/s in a diseased glomerulus may give origin, after specific immunoglobulin and complement binding, to a superimposed glomerulopathy, probably worsening the prognosis of the primary glomerular injury.

The suggested pathogenesis of the glomerulopathies associated with mansonian schistosomiasis are schematically shown below. There are more questions than answers related to the pathogenesis of glomerular injury in this parasitic disease.

\section{ACKNOWLEDGEMENTS}

Financial support for this project was provided by CNPq (300857 / $94 \mathrm{RN}$ ) and LIM-06.

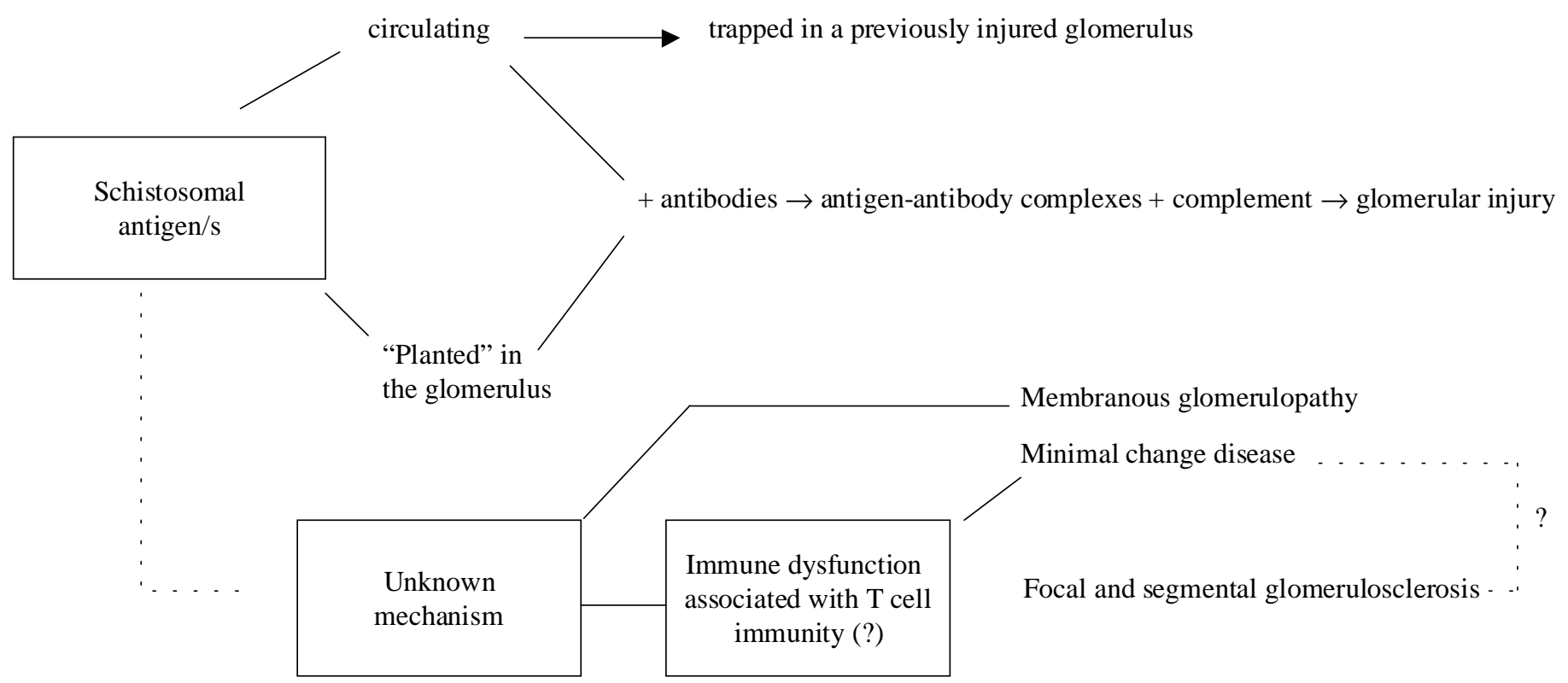

\section{REFERENCES}

1. ABENSUR, H.; NUSSENZVEIG, I.; SALDANHA, L.B. et al. - Nephrotic syndrome associated with hepatointestinal schistosomiasis. Rev. Inst. Med. trop. S. Paulo, 34: 273-276, 1992

2. ABRASS, C.K. - Mechanisms of immune complex formation and deposition in renal structures. In: NEILSON, E.G. \& COUSER, W.G., ed. Immunologic renal diseases. Philadelphia, Lippincott-Raven, 1997. p. 291-307.

3. ACETI, A.; TALIANI, G.; BRUNI, R. et al. - Hepatitis C virus infection in chronic liver disease in Somalia. Amer. J. trop. Med. Hyg., 48: 581-584, 1993.

4. ANDRADE, Z.A. \& QUEIROZ, A.C. - Lesões renais na esquistossomose hepatoesplênica. Rev. Inst. Med. trop. S. Paulo, 10: 36-40, 1968.

5. ANDRADE, Z.A. \& ROCHA, H. - Schistosomal glomerulopathy. Kidney Int., 16: 23 $29,1979$.

6. ANDRADE, Z.A.; ANDRADE, S.G. \& SADIGURSKY, M. - Renal changes in patients with hepatosplenic schistosomiasis. Amer. J. trop. Med. Hyg., 20: 77-83, 1971.

7. ANDRADE, Z.A. \& VAN MARCK, E.A.E. - Schistosomal glomerular disease (a review) Mem. Inst. Oswaldo Cruz, 79: 499-506, 1984.

8. BARSOUM, R.S. - Schistosomal glomerulopathies. Kidney Int., 44: 1-12, 1993.
9. BARSOUM, R.; NABIL, M.; SAADY, G. et al. - Immunoglobulin A and the pathogenesis of schistosomal glomerulopathy. Kidney Int., 50: 920-928, 1996.

10. COUSER, W.G. - Mechanisms of glomerular injury in immune-complex disease. Kidney Int., 28: 569-583, 1985.

11. CRAIG TISHER, C.C. \& BRENNER, B.M. - Renal Pathology with clinical and functional correlations. $2^{\text {nd }}$ ed. Philadelphia, J.B. Lippincott, 1994. p. 330-345.

12. DAUDA, R.; PETERSON, J.; WEINER, R.; CROKER, B. \& LAU, J.Y. - Membranous glomerulonephritis in association with hepatitis $C$ virus infection. Amer. J. Kidney Dis., 22: 452-455, 1993.

13. DE BRITO, T.; GUNJI, J.; CAMARGO, M.E.; PENNA, D.O. \& SILVA, L.C. - Advanced kidney disease in patients with hepatosplenic Manson's schistosomiasis. Rev. Inst. Med. trop. S. Paulo, 12: 225-235, 1970.

14. DE BRITO, T.; CARNEIRO, C.R.W.; NAKHLE, M.C. et al. - Localization by immunoelectron microscopy of Schistosoma mansoni antigens in the glomerulus of hamster (Mesocricetus auratus) kidney. Exp. Nephrol., 6: 368-376, 1998.

15. DE BRITO, T.; NUSSENZVEIG, I.; CARNEIRO, C.R.W. et al. - Glomerular detection of schistosomal antigen by immunoelectron microscopy in human mansonian schistosomiasis. Int. J. surg. Path., 7: 217-225, 1999.

16. DEELDER, A.M ; KLAPPE, H.T.M; VAN DEN AARDWEG, G.J.M. \& VAN MEERBEKE, E.H.E.M. - Schistosoma mansoni: demonstration of two circulating antigens in infected hamsters. Exp. Parasit., 40: 189-197, 1981. 
17. DE WATER, R.; VAN MARCK, E.A.E.; FRANSEN, J.A.M. \& DEELDER, A.M. Schistosoma mansoni: ultrastructural localization of the circulating anodic antigen and the circulating cathodic antigen in the mouse kidney glomerulus. Amer. J. trop. Med. Hyg., 38: 118-124, 1988.

18. EL-SHERIF, A. \& BEFUS, D. - Predominance of IgA deposits in glomeruli of Schistosoma mansoni infected mice. Clin. exp Immunol., 71: 39-44, 1988.

19. FALCÃO, H. \& GOULD, D.B. - Immune complex nephropathy in schistosomiasis. Ann. intern. Med., 83: 148-154, 1975.

20. HENDRICKSE, R.G. \& ADENIYI, A. - Quartan malarial nephrotic syndrome in children. Kidney Int., 16: 64-74, 1979.

21. HIBBS, R.G.; CORWIN, A.L.; HASSAN, N.F. et al. - The epidemiology of antibody to hepatitis C in Egypt. J. infect. Dis., 168: 789-790, 1993.

22. HOSHINO-SHIMIZU, S.; DE BRITO, T.; KANAMURA, H. et al. - Human schistosomiasis: S.mansoni antigen detection in renal glomeruli. Trans. roy. Soc. trop. Med. Hyg., 70: 492-496, 1976.

23. HOUBA, V. - Experimental renal disease due to schistosomiasis. Kidney Int., 16: 3043,1979 .

24. HUNTE, W. \& AL-GHAOUI, F. - Secondary syphilis and the nephrotic syndrome. J. Amer. Soc. Nephrol., 3: 1351-1355, 1993.

25. JOHNSON, R.J.; GRETCH, D.R.; YAMABE, H. et al. - Membranoproliferative glomerulonephritis associated with hepatitis $C$ virus infection. New Engl. J. Med., 328: 465-470, 1993.

26. KEVIN KRANE, N.K.; ESPENAM, P.; WALKER, P.D.; BERGMAN, S.M. \& WALLIN, J.D. - Renal disease and syphilis: a report of nephrotic syndrome with minimal change disease. Amer. J. Kidney Dis., 9: 176-179, 1987.

27. LAI, K.N.; RAINBOW, T.H.; HO, J.S.T. \& LAI, F.M. - Detection of hepatitis B virus DNA and RNA in kidneys of HBV-related glomerulonephritis. Kidney Int., 50: 1965-1977, 1996

28. MAGALHÃES FILHO, A.G.; BARBOSA, A.V. \& FERREIRA, T.C. - Glomerulonephritis in schistosomiasis with mesangial IgM deposits. Mem. Inst. Oswaldo Cruz, 76: 181-188, 1981.

29. MORIEARTY, P.L. \& BRITO, E. - Elution of renal antischistosome antibodies in human schistosomiasis mansoni. Amer. J. trop. Med. Hyg., 26: 717-722, 1977.
30. NAGASHIMA, R.; MAEDA, K.O.; YUDA, F. et al. - Helicobacter pylori antigen in the glomeruli of patients with membranous nephropathy. Virchows Arch. path. Anat. 431: 2335-2339, 1997.

31. NATALI, P.G. \& CIOLI, D. - Immune-complex nephritis in Schistosoma mansoni infected mice. Europ. J. Immunol., 6: 359-364, 1976.

32. O'REGAN, S.; FONG, J.S.C.; CHADARÉVIAN, J.P.; RISHIKOF, J.R. \& DRUMMOND K.N. - Treponemal antigens in congenital and acquired syphilitic nephritis. Ann. intern. Med., 85: 325-327, 1976.

33. RAMOS, E.A.G. \& ANDRADE, Z.A. - Chronic glomerulonephritis associated with hepatosplenic schistosomiasis mansoni. Rev. Inst. Med. trop. S. Paulo, 29: 162$167,1987$.

34. RITZ, E. - Pathogenesis of "idiopathic" nephrotic syndrome (Editorial). New Engl. J. Med., 330: 61-62, 1994.

35. SILVA, L.C.; DE BRITO, T.; CAMARGO, M.E. et al. - Kidney biopsy in the hepatosplenic form of infection with S. mansoni in man. Bull. Wld. Hlth. Org., 42: 907-910, 1970.

36. SOBH, M.A.; MOUSTAFA, F.E.; EL-HOUSSEINI, F. et al. - Schistosomal specific nephropathy leading to end-stage renal failure. Kidney Int., 31: 1006-1011, 1987.

37. SOBH, M.; MOUSTAFA, F.; EL-ARBAGY, A. et al. - Nephropathy in asymptomatic patients with active Schistosoma mansoni infection. Int. Urol. Nephrol., 22: 37-43, 1990.

38. SOBH, M.; MOUSTAFA, F.E.; HAMED, S.M. \& GHONEIM, M.A. - Infectious glomerulopathy induced by a defined agent (Schistosoma mansoni): progression despite early elimination of the causal agent. Exp. Nephrol., 1: 261-264 , 1993.

39. STEHMAN-BREEN, C.; ALPERS, C.E.; FLEET, W.P. \& JOHNSON, R.J. - Focal segmental glomerular sclerosis among patients infected with hepatitis $\mathrm{C}$ virus. Nephron, 81: 37-40, 1999.

40. TOURVILLE, D.R.; BYRD, L.H.; KIM, D.U. et al. - Treponemal antigen in immunopathogenesis of syphilitic glomerulonephritis. Amer. J. Path., 82: 479-492, 1976.

41. VAN VELTHUYSEN, M.L.F. - Glomerulopathy associated with parasitic infections. Parasit. today, 12: 102-107, 1996.

42. YAMABE, H.; INUMA, H.; OSAWA, H. et al. - Glomerular deposition of hepatitis C virus in membranoproliferative glomerulonephritis. Nephron, 72: 741, 1996.

Received: 21 July 1999

Accepted: 23 September 1999 